\title{
Application of Integrated Reservoir Management and Reservoir Characterization to Optimize Infill Drilling
}

\author{
Annual Report \\ June 13, 1996 - June 12, 1997
}

\begin{abstract}
By:
J.W. Nevans; T. Blasingame; L. Doublet; G. Freeman

J. Callard; D. Moore; D. Davies; R. Vessell; B. Pregger
\end{abstract}

Work Performed Under Contract No.: DE-FC22-94BC14989

\author{
For \\ U.S. Department of Energy \\ Office of Fossil Energy \\ Federal Energy Technology Center \\ P.O. Box 880 \\ Morgantown, West Virginia 26507-0880
}

By

Fina Oil \& Chemical Company

6 Desta Drive

Suite 4400

Midland, Texas 79701 


\section{Disclaimer}

This report was prepared as an account of work sponsored by an agency of the United States Government. Neither the United States Government nor any agency thereof, nor any of their employees, makes any warranty, express or implied, or assumes any legal liability or responsibility for the accuracy, completeness, or usefulness of any information, apparatus, product, or process disclosed, or represents that its use would not infringe privately owned rights. Reference herein to any specific commercial product, process, or service by trade

name, trademark, manufacturer, or otherwise does not necessarily constitute or imply its endorsement, recommendation, or favoring by the United States Government or any agency thereof. The views and opinions of authors expressed herein do not necessarily state or reflect those of the United States Government or any agency thereof. 


\title{
"APPLICATION OF INTEGRATED RESERVOIR MANAGEMENT AND RESERVOIR CHARACTERIZATION TO OPTIMIZE INFILL DRILLING"
}

\author{
ANNUAL TECHNICAL PROGRESS REPORT
}

REPORTING PERIOD: 06/13/96 TO 06/12/97

\begin{abstract}
JERRY W. NEVANS (FINA OIL \& CHEMICAL) TOM BLASINGAME (TEXAS A\&M UNIVERSITY)

LOUIS DOUBLET (TEXAS A\&M UNIVERSITY) GEORGE FREEMAN (UNIVERSITY OF TULSA)

JEFF CALLARD (UNIVERSITY OF TULSA) DAVID MOORE (SCIENTIFIC SOFTWARE, INC.) DAVID DAVIES (DAVID K. DAVIES \& ASSOCIATES) RICHARD VESSELL (DAVID K. DAVIES \& ASSOCIATES) BRIAN PREGGER (FINA OIL \& CHEMICAL)
\end{abstract}

DATE ISSUED: AUGUST 1997

PROJECT NO.: DE-FC22-94BC14989--13

FINA OIL \& CHEMICAL COMPANY

6 DESTA DRIVE, SUITE 4400

MIDLAND, TEXAS 79701 


\section{APPLICATION OF INTEGRATED RESERVOIR MANAGEMENT AND RESERVOIR CHARACTERIZATION TO OPTIMIZE INFILL DRILLING}

\section{ANNUAL REPORT}

Table of Contents

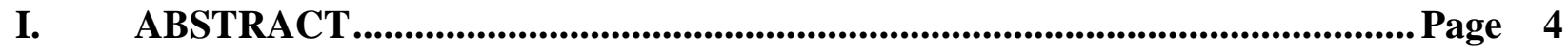

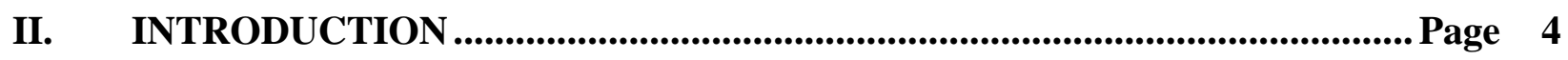

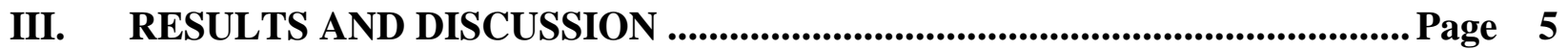

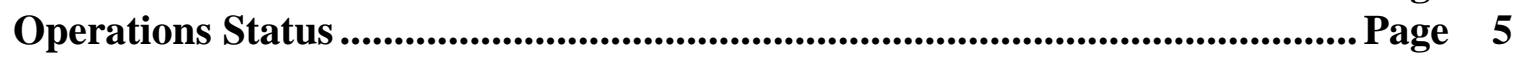

Coring Operations \& Analysis...............................................................................Page 5

Geology/Deposition.............................................................................................Page 7

Special Core Analysis ............................................................................................Page 8

Open Hole Logging....................................................................................................Page 9

Well Completions............................................................................................................Page 10

Material Balance Decline Curve Analysis ............................................................ Page 10

Geostatistical................................................................................................................ Page 11

Deterministic.................................................................................................................. Page 11

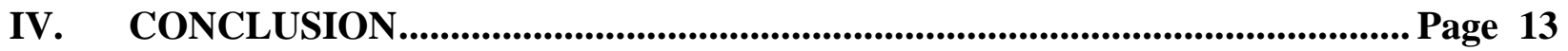

V. PUBLICATIONS AND PRESENTATIONS....................................................... Page 14

VI. REFERENCES .................................................................................................. Page 14 


\begin{abstract}
Infill drilling of wells on a uniform spacing, without regard to reservoir performance and characterization, does not optimize reservoir development because it fails to account for the complex nature of reservoir heterogeneities present in many low permeability reservoirs, and carbonate reservoirs in particular. New and emerging technologies, such as geostatistical modeling, rigorous decline curve analysis, reservoir rock typing, and special core analysis can be used to develop a 3-D simulation model for prediction of infill locations.
\end{abstract}

\title{
INTRODUCTION
}

The purpose of this project is to demonstrate the application of advanced secondary recovery technologies to remedy producibility problems in typical shallow shelf carbonate reservoirs of the Permian Basin, Texas. Typical problems include poor sweep efficiency, poor balancing of injection and production rates, and completion techniques that are inadequate for optimal production and injection. 


\section{RESULTS AND DISCUSSION}

\section{OPERATIONS STATUS}

During the Field Demonstration Phases of the project a total of 18 wells, 14 producers and 4 injection wells, were drilled and completed on schedule. Eleven (11) wells were drilled during the second quarter, consisting of nine (9) producing wells and two (2) injection wells. Ten (10) of the wells were drilled to complete waterflood patterns in the North (Section 329) and South (Section 327) 10-acre infill areas of the Unit. An additional off-pattern well, NRU 3319, was drilled in Section 362 of the Unit in a 20 -acre location that had not previously been drained by existing producers.

Seven (7) wells were drilled during the third quarter of 1996, consisting of five (5) producers and two (2) injection wells. This phase of drilling consisted of completing waterflood patterns to the West of the wells in Section 329 and Section 327 of the Unit. An additional off-pattern well, NRU 3604, was drilled in a 10-acre location in the southwest corner of Section 324, in an area of the Unit in which reservoir flow simulation predicted extremely high recovery potential. Production flowlines were laid for each new producing well as they were put on production. Injection flowlines were laid for the injection wells as they were completed.

All wells are in service with no operational problems. The producing wells are currently producing a total of approximately 650 bopd, down from a peak rate of 900 bopd. Unit production is averaging approximately 3,000 bopd, 12,000 bwpd, 18,000 bwipd. Early results indicated that approximately $65 \%$ of the production from the new infill wells was incremental and approximately $35 \%$ was acceleration of existing reserves. On an individual well basis, some of the additional production in Section 329 of the Unit appears to be due to acceleration of existing reserves, while most of the additional production in Sections 326 and 327 appears to be incremental. These trends were predicted prior to drilling on the basis of differing reservoir rock types that occur in the two areas. The Section 329 infill area is dominated by grainstone shoal facies with fairly good permeability and porosity characteristics. The reservoir within Sections 326 and 327 is dominated by lagoonal facies with good storage capacity (porosity), but relatively lower permeability and connectivity.

The approved revision in the Statement of Work allows for the potential of drilling additional 10acre infill wells and/or 20-acre producing wells to injection as allowed by budget constraints.

\section{CORING OPERATIONS \& ANALYSIS}

A total of 2,730 feet of core was taken from four (4) wells during the Field Demonstration portion of the Project as part of an intensive effort to collect needed rock data. Geologists were very careful to capture high quality data from the core by following these rigorous procedures: 
(1) The core was pulled from the barrel and loaded into six inch (6") PVC tubes that were immediately filled with degassed lease crude and then sealed.

(2) The core was carefully laid out at the lab ensuring that care was taken to properly mark depths and lost core intervals.

(3) One inch by one inch (1"x 1") plugs were taken every foot, exactly one-tenth (0.1) feet below the foot mark. These plugs were measured by Core Labs for helium porosity, air permeability, and grain density. All of this data was loaded into a geological-petrophysical computer database program, then depth shifted.

(4) 'Whole' core analyses were taken at promising-looking reservoir intervals. Data was loaded into the computer database and depth corrected.

(5) One and one-half inch by three inch (1.5" x 3") Special Core Analysis (SCAL) plugs were taken in all potential reservoir intervals and in all rock types. These plugs were stored in sealed containers filled with degassed lease crude to preserve the native state of the rock characteristics and fluid content.

(6) Fina slabbed all the core at their own facility to maintain high quality assurance.

(7) Depositional environment and rock type using Dunham's classification were described from the slabbed core.

(8) Permeabilities and porosities were measured from a selected one-hundred fifty feet (150') of the NRU 3533 core using Core Labs PDK-100 mini-permeameter machine. Three (3) permeability traces, one-tenth inches (0.1") apart, were recorded. Measurements were taken vertically each one-tenth inch (0.1"). Acoustic-measured porosities were also recorded, using one trace down the center of the core slab, every one-tenth inch (0.1").

The original schedule called for cutting 1,200' of continuous core through the entire Clearfork Formation from three (3) separate wells, for a total of 3,600'. This continuous core gives the ability to make foot by foot comparisons of reservoir quality, rock type and depositional environment which ultimately helps to correct model fluid movement within the reservoir. However, due to significant mechanical difficulties caused by very long core times, often greater than 200 minutes per foot, parts of the section were not cored.

The data was used to help quantify the extent of small scale vertical and lateral heterogeneity, refine the depositional model and improve the understanding of the relationship between porosity and permeability. This data will also assist in the process of choosing additional 10-acre drilling locations within the NRU Clearfork Formation. 


\section{GEOLOGY/DEPOSITION}

The depositional environments described from the core samples are as follows:

\section{Open Shelf}

- Open-Shelf General

- Fusilinid Shoal

- Shoal - General

- Inter - Shoal

\section{Reef}

- Reef Center

- Reef Talus Apron

- Reef Debris Apron

\section{Open Lagoon}

\section{Restricted Lagoon}

The first significant new feature is the presence of large patch reefs and associated porous debris aprons in the Lower Clearfork within Section 327. Initial work suggested that a "shelf" edge existed to the east of Section 327, and that large reefs only existed along this edge. New core information implied there was no "shelf" edge, just patch reefs and debris aprons scattered across the Unit. This could help explain the erratic distribution of good producing wells in the southcentral portion of the Unit. It is important to note that the debris aprons and shoals around these reefs typically have good quality. In addition, smaller and less well developed reefs and bioherms have been noted in the upper portions of the Middle Clearfork and Upper Clearfork.

The second new feature concerns the MF3 layer (+/-6,850') of the Middle Clearfork that is interpreted as a solution collapse breccia with associated open natural fractures. These features were caused by dissolution of carbonate beneath extensive exposure surfaces. The presence of these surfaces is supported by presence of coal beds, abundant "fresh" water plant debris zones, erosion lag soils and some root casts. Parts of the Unit were only partially exposed, most probably a series of small islands and associated carbonate sand beaches. This information became of significant economic importance since there is more natural fracturing in the MF3 Zone that initially thought.

The faunal assemblage analysis of $125^{\prime}$ of core from three wells revealed the presence of several bryozoan genera, codiacean and coralline red algae, rugose corals, gastropods, crinoids, brachiopods of the composite type, foraminifera and several genera of fusulinid foraminifera. Of particular interest was the occurrence of cyclostome bryozoa as the main frame-builder of the patch reefs in the Lower Clearfork. The bryozoa have erect laminar and bifoliate growth forms 
which appear to have formed an effective sediment baffle. The growth forms are massive and robust, indicating a moderate to high energy depositional environment. Six genera of cyclostome bryozoa were identified in these reefs. The reefs contain bryozoa both in growth position and as desegregated, overturned fragments floating in a muddy matrix. Core analysis reveals that the reefs are non-porous and tight. Surrounding reef talus and reef debris aprons are very porous and permeable, containing some of the highest permeability in the Clearfork.

Fina has described four basic rock fabrics in this Unit:

Homogenous. Is made up of relatively uniformly distributed lateral and vertical porosity and permeability. A good example is found within selected portions of the MF1A layer. This zone is not perfectly homogenous but is much closer to this type than all other zones in the Clearfork.

Fractured. Is made up of solution collapse breccias as described above. Fractures are $2 "-4$ " in length and very roughly estimated to be 4"-6" apart. The fractures that are not open have been plugged with anhydrite. Portions of the MF3 layer are a good sample of this fabric.

Bimodal. Is made up of two distinct pore sizes. The larger size pores are typically formed from the dissolution of fossil debris and the smaller pores are typically intercrystalline in origin.

Heterogeneous. Is made up of anhydrite nodules and porous dolostone. This fabric is common throughout much of the Glorieta/Clearfork section. The size and distribution of these anhydrite nodules vary dramatically.

\section{SPECIAL CORE ANALYSIS}

Approximately 120 preserved ( 3 inch by 1.5 inch) core plugs were cut from the new whole core in 10-acre infill Wells 1509, 3533, 1510, and 3319 in order to obtain a representative sampling of all 'pay' rock types that were defined during Budget Period I. Thin-section descriptions and capillary pressure measurements are being obtained from the clipped ends of all 120 core plugs.

The SCAL plugs were further screened both visually (thin-sections and slabbed core), and by using a computerized axial tomography (CT) scanning machine at Texas A\&M University to eliminate the plugs that possessed major barriers to flow, which are almost always in the form of anhydrite nodules. A CT number of 2550 and above indicates the presence of extensive anhydrite. Pure dolomite has a CT number of about 2350 and the number for pure limestone is around 2250. CT numbers less than 2200 are indicative of good porosity or fracturing.

These studies allowed us to choose 46 plugs, representing the reservoir rock types (Rock Types $1,2,3$, and 5), for special core studies. The special core analysis program is intended to improve the characterization and description of the reservoir and to provide better reservoir property data for flow simulation. 
The Special Core Analysis program was originally intended to measure properties for each of the four significant reservoir rock types in order for properties to be correlated with rock types. This has been impractical due to low permeabilities of the SCAL plugs to permit measurement of the desired properties in a reasonable amount of time for all but the highest quality rock type (Type 1). Therefore, only Rock Type 1 has a complete set of SCAL measurements. This rock type constitutes a small portion of the rock volume but has the greatest effect on reservoir productivity.

\section{OPEN HOLE LOGGING}

The base logging suite for the 10-acre infill consisted of:

- Mud Logging

- Dual Laterolog

- Micro Laterolog

- Micro-Spherically Focused Log $\left(\mathrm{R}_{\mathrm{xo}}\right.$ device $)$

- Compensated Neutron Log

- Compensated Spectral or Litho-Density Log (includes PE)

- Spectral Gamma Ray Log

- Sonic Log

In addition to the aforementioned logging suite, to more accurately characterize permeability, fluid content and rock fabric, Fina utilized:

- High Frequency Dielectric Log

- NMR Log

- Borehole Imaging Log.

By using multiple geologic "filters" it is possible to dramatically reduce the scatter on porosity versus permeability crossplots, thereby providing more robust algorithms. "Filters" include devices such as depositional environment data, shallowing upward sequence tops, rock type data, mud log data and numerous open-hole log responses (PE, Spectral Gamma-Ray, Invasion Profile, etc.). Neural network technology allows for the combination of curve data in order to locate unique permeability signatures.

As a result of the data acquisition process (core and logs) during the Field Demonstration Phase of the Project, Fina identified discrete intervals within the Glorieta/Clearfork section that contributed most to production. Intervals of relatively high permeability and porosity reservoir, which are separated by larger intervals of lower permeability and porosity rock that act as source beds for the higher quality reservoir rock. These intervals include:

Lower Clearfork: $\quad$ MF4 and MF5 Zones $\quad$ (+/-7,000'-7,200')

Middle Clearfork: $\quad$ MF1A, MF2, and MF3 Zones (+/-6,350'-6,500' and +/-6,750'-6,900')

Upper Clearfork: $\quad$ CF4 Zone (varies in Unit) (+/-6,150'-6,200’) 


\section{WELL COMPLETIONS}

Fina utilized three-stage completion designs to keep intervals between 100' and 250'. Both $\mathrm{CO}_{2}$ foam fracs and conventional cross-linked borate fracs using a new premium frac fluid on an equal number of new wells, with outstanding results for both designs. The advantages of each type are listed below:

\section{$\mathrm{CO}_{2}$ Foam Fracs}

- Exceptionally clean frac fluid

- Increased relative oil permeability

- Created solution gas drive reduces cleanup requirements

- Formation of carbonic acid for near-well stimulation

- Reduction in interfacial tension helps remove water blocks

\section{Cross-Linked Borate}

- Exceptional clean frac fluid

- Low fluid loss without formation-damaging additives

- Excellent proppant-carrying capacity

- Polymer-specific enzyme breaker aids in post-frac cleanup

- $90 \%$ of original fracture conductivity retained

These wells were radioactively traced to estimate vertical fracture propagation. This technique avoided fracturing down into an underlying water zone in the Lower Clearfork along with avoiding any fracture communication between stages. Hydraulic fracture jobs were designed to yield fracture half-lengths of approximately 150'. Post-frac pressure transient tests performed over specific completion intervals indicate that we are obtaining fracture half-lengths between 80'120' with average radial flow skin factors of approximately -5.0.

All of the well's rates have held up extremely well over time for both types of hydraulic fracture designs. The major factor controlling initial potential appears to be confinement of the vertical completion interval and localized reservoir quality.

\section{MATERIAL BALANCE DECLINE CURVE ANALYSIS}

Production data from new 10-acre infill wells was analyzed utilizing material balance decline type curve methodologies. Rate and fluid level measurements allowed verification of results from previous analyses, to obtain estimates of individual well potentials, bottomhole pressures, and formation flow characteristics. Below is a brief summary of results: 


\begin{tabular}{|c|c|c|c|c|c|}
\hline \multicolumn{7}{|c|}{$\begin{array}{c}\text { OOIP Calc. } \\
\text { NRU Well }\end{array}$} & $\begin{array}{c}\text { Est. EUR } \\
\text { Calc. } \\
\text { (RF=10\%) } \\
\text { (STB) }\end{array}$ & $\begin{array}{c}\text { Drainage } \\
\text { Area Calc. } \\
\text { (acres) }\end{array}$ & Xf (ft) & kh (md-ft) \\
\hline \multicolumn{7}{|c|}{ Section 327 Infill Area } \\
\hline NRU 505 & 879,300 & 87,928 & 16.3 & 316.5 & 4.81 \\
\hline NRU 1509 & 621,100 & 62,105 & 11.5 & 199.5 & 4.38 \\
\hline NRU 1511 & 851,300 & 85,128 & 15.7 & 133.5 & 22.59 \\
\hline NRU 2705 & 524,800 & 52,476 & 9.7 & 73.4 & 7.12 \\
\hline NRU 3017 & 503,300 & 50,327 & 9.3 & 119.7 & 4.77 \\
\hline NRU 3018 & 755,900 & 75,594 & 14.0 & 220.1 & 16.99 \\
\hline \multicolumn{7}{|c|}{ Section 362 Infill Area } \\
\hline NRU 3319 & $1,779,000$ & 177,896 & 32.9 & 337.7 & 9.64 \\
\hline \multicolumn{7}{|c|}{ Section 329 Infill Area } \\
\hline NRU 3532 & 842,100 & 84,211 & 15.6 & 232.3 & 7.82 \\
\hline NRU 3533 & $1,206,000$ & 120,563 & 22.3 & 370.7 & 17.08 \\
\hline NRU 3534 & 706,200 & 70,621 & 13.1 & 212.8 & 11.50 \\
\hline NRU 3535 & 745,800 & 74,575 & 13.8 & 145.8 & 36.39 \\
\hline NRU 3604 & 758,300 & 75,829 & 14.0 & 126.0 & 14.28 \\
\hline TOTALS & $\mathbf{1 0 , 1 7 3 , 0 0 0}$ & $\mathbf{1 , 0 1 7 , 3 0 0}$ & & & $\mathbf{1 3 . 1 1}$ \\
\hline AVERAGES & $\mathbf{8 4 7 , 7 1 1}$ & $\mathbf{8 4 , 7 7 1}$ & $\mathbf{1 5 . 7}$ & $\mathbf{2 0 7 . 3}$ & \\
\hline
\end{tabular}

\section{GEOSTATISTICAL}

A new reservoir simulation model was developed and is termed a four (4) layer model because it utilizes four (4) different permeabilities which were derived honoring the logarithmic distribution of permeability observed in the core data. This technique avoids individual well history matches but instead tries to capture the behavior of the study area as a whole. The new four layer model proved to be of great value in the reservoir characterization efforts at North Robertson Unit. Major points of the new model are that run time is reduced to $1 \%$ and grid properties do not require input from the rock log solution. The combination of modeling regional production with a simplified model allows the engineer to examine many hypotheses in a timely fashion.

\section{DETERMINISTIC}

At the end of Budget Period I of the North Robertson study, several technology transfer workshops were presented. These workshops provided an opportunity for various team members to review all phases of the study and discuss the current status of the reservoir description from the perspective of each of the disciplines involved. This review suggested an improved reservoir description for the simulation models which could yield a more accurate history match without requiring an additional aquifer layer, aquifer functions, or many of the modifications made to the initial reservoir and well descriptions in the previous studies. This alternative description involved a dual-porosity approach in which the simulation lawyers are divided into two rock groups: the 
very low permeability matrix and the higher permeability flow zones. The Glorietta and Upper Clearfork layers consist primarily of the low permeability matrix with few higher permeability streaks. The Middle and Lower Clearfork layers have a larger proportion of the higher permeability rock. The poor quality matrix has high water saturations (irreducible and capillary) and contributes to reservoir performance primarily through expansion of fluids into the higher permeability streaks. Nearly all of the true fluid flow occurs in these higher quality layers which are connected to the wells by hydraulic fractures. During the early portion of the history period, water production occurred through expansion of fluids (oil, gas and water) in the matrix, which forced water into the higher permeability layers and eventually to the wells. When water injection began, water flowed directly from injector to producer through the hydraulic fractures and higher permeability layers, by-passing much of the low quality matrix. As can be imagined, this reservoir description can give very different predictions of future reservoir behavior than the previous description.

During the first quarter of 1997, the following tasks were completed:

(1) The Section 329 Glorieta/Clearfork reservoir simulation model was converted from a fully composition fluid characterization ( 7 components) to a standard blackoil fluid characterization.

(2) A modified Todd-Longstaff miscible fluid treatment was added to the standard black-oil model developed in (1).

(3) A dual-porosity reservoir description was added to the single-porosity model developed in (1).

(4) Both a dual-porosity formulation and the modified Todd-Longstaff miscible treatment were added to the single-porosity, standard black-oil model developed in (1).

(5) The nineteen layer, dual porosity, standard black-oil model in (3) was converted to a ten-layer, dual-porosity, standard black-oil model.

In addition, the new black-oil laboratory fluid data was analyzed and incorporated into the simulation models. This accomplished through the following tasks:

(1) Black-oil fluid properties from tuned equation of state were generated.

(2) New laboratory data was compared to previous data.

(3) A new equation-of-state fluid characterization was generated and tuned.

(4) New compositional and black-oil characterizations in simulators were tested. 
The work listed above was performed primarily to answer the following questions:

(1) Can the Clearfork reservoir behavior be accurately simulated using black-oil fluid characterization?

(2) Is the reservoir behavior better represented by a dual-porosity geologic characterization than by the single-porosity description used previously?

(3) Can the number of layers in the simulation model be reduced from twenty (20) to ten (10), without a significant loss of accuracy?

Based on the results of this work, the answer to each of these questions is YES. A better history match was obtained with the black-oil, dual-porosity model than with the previous compositional, single-porosity model. Most importantly, the match was obtained relatively easily with few modifications to the original reservoir and well descriptions. No aquifer layer or aquifer functions were required. Multiple relative permeability and capillary pressure tables were not needed. It was not necessary to assume that injection water was leaving the reservoir or that some of the produced water had entered the reservoir from an outside source. Modifications to matrix porosities and permeabilities were not required. Changes to the completion intervals of the well were generally not necessary. And it was possible to perform hydraulic fracture stimulations in the model at the dates of the actual stimulations. In general, the only modifications require to the initial reservoir description were to adjust the properties and distribution of the high-permeability layers. Nearly all modifications were performed on a layer basis with little need to vary reservoir characteristics within layers.

These improvements to the reservoir descriptions of the simulation models resulted directly from the integrated approach to reservoir management in this study. The work performed by the various team members is constantly being integrated into a single, consistent reservoir characterization which evolves as new data and improved interpretations become available. This continuing evolution of the reservoir characterization greatly facilitates the optimization of infill drilling in the North Robertson Unit.

\section{CONCLUSION}

The use of specialized techniques, such as geostatistical modeling, rigorous decline curve analysis, reservoir rock typing and special core analysis is proving to be a great aid in the selection of infill locations at the North Robertson Unit. The results of the eighteen (18) wells which were drilled as part of this project are significantly better than previous infill wells, which were drilled without regard to reservoir performance or characterization. These new technologies can account for the complex nature and high degree of heterogeneity present in low permeability reservoirs such as the North Robertson Unit, and provide better data for use in developing an accurate 3-D simulation model. 


\section{PUBLICATIONS AND PRESENTATIONS}

\section{Annual DOE/BDM International Reservoir Characterization Technical} Conference, March 2-4, 1997, Houston, TX.

- $\quad$ Oral presentation and poster session on project material.

- $\quad$ "Improved Characterization of Reservoir Behavior by Integration of Reservoir Performance Data and Rock Type Distributions."

Oklahoma Geological Society Circular, Platform Carbonates in the Southern MidContinent, (in press), K.S. Johnson, March 1997.

- $\quad$ "Environments of Deposition for the Clear Fork and Glorietta Formations, North Robertson Unit, Gaines County, Texas.”

1997 BDM/DOE Annual Contractor Review Meeting, June 16-20, Houston, TX.

- Oral presentation

\section{REFERENCES}

Calhoun, J.C.: “Fundamentals of Reservoir Engineering," University of Oklahoma Press, Norman, OK. (1982).

David K. Davies \& Associates, Inc.: “Geological-Petrophysical Reservoir Characterization, presented at North Robertson Unit internal meeting, July 13, 1993, Midland, TX.

David K. Davies \& Associates, Inc.: "Reservoir Characterization to Optimize the Infill Drilling and Enhanced Recovery," presented at North Robertson Unit/DOE internal meeting, January 3, 1996, Tulsa, OK.

Ehrlich, R. and Davies, D.K.: "Image Analysis of Pore Geometry: Relationship to Reservoir Engineering and Modeling," paper SPE 19054 presented at the 1989 SPE Gas Technology Symposium, Dallas, TX, June7-9.

Wardlaw, NC and Cassan, J. P.: "Estimation of Recovery Efficiency by Visual Observation of Pore Systems in Reservoir Rocks,” Bulletin Canadian Petroleum Geology, 26 (1978).

Thomeer, J.M.: “Introduction of a Pore Geometrical Factor Defined by the Capillary Pressure Curve,” JPT, (March 1960), 73-77.

Stiles, L.H.: “Optimizing Waterflood Recovery in a Mature Waterflood, The Fullerton Clearfork Unit,” paper SPE 6198, presented at the 1976 SPE Annual Fall Technical Conference and Exhibition, New Orleans, LA, October 3-6.

Barber, A.H., et al: "Infill Drilling to Increase Reserves - Actual Experience in Nine Fields in Texas, Oklahoma and Illinois,” JPT, (August, 1983) 1530-1538. 
Hutt, P. R., et al: "Applications of Cross-Borehole Seismic Tomography to Monitor EOR Displacement Fronts in Heavy Oil Fields of Kern County, California," paper SPE 19855 presented at the 1989 SPE Annual Technical Conference and Exhibition, San Antonio, TX, October 8-11.

Harris, J. M.: “Cross-Well Seismic Measurements in Sedimentary Rocks,” paper SPE 19871 presented at the 1989 SPE Annual Technical Conference and Exhibition, San Antonio, TX, October 8-11.

Doublet, L. E., et al: "Decline Curve Analysis Using Type Curves-Analysis of Oil Well Production Data Using Material Balance Time: Application to Field Cases," paper SPE 28688 presented at the 1994 Petroleum Conference and Exhibition of Mexico, Veracruz, Mexico, October 10-13.

Fetkovich, M. J.: “Decline Curve Analysis Using Type Curves,” JPT (June 1980) 1065-1077.

McCray, T. L.: “Reservoir Analysis Using Production Decline Data and Adjusted Time," MS Thesis, Texas A\&M University, College Station, TX (1990).

Palacio, J.C. and Blasingame, T. A.: "Decline Curve Analysis Using Type Curves: Analysis of Gas Well Production Data," paper SPE 25909 presented at the 1993 SPE Rocky Mountain Regional/Low Permeability Reservoirs Symposium, Denver, CO, April 12-14.

Doublet, L. E. and Blasingame, T. A.: "Evaluation of the Injection Well Performance Using Decline Type Curves,” paper SPE 35205 presented at the 1996 SPE Permian Basin Oil and Gas Recovery Conference, Midland, TX, March 27-29.

PanSystem ${ }^{\mathrm{TM}}$-Well Test Analysis Program (Version 1.8), Edinburgh Petroleum Services, Ltd. Edinburgh, Scotland, UK, April 1991.

Banthia, B. S., Meyer, B. J., and Blasingame, T. A.: "Use of Surface-Derived Pressure Measurements for Cost-Effective Reservoir Surveillance of Waterflood Operations in the Permian Basin," paper SPE 27685 presented at the 1994 SPE Permian Basin Oil and Gas Recovery Conference, Midland, TX, March 16-18.

Hearn, C. L.: “Method Analyzes Injection Well Pressure and Rate Data,” Oil and Gas Journal (April 1983) 117-120.

Muskat, M.: “Physical Principles of Oil Production,” McGraw-Hill Book Co., Inc., New York (1949), 682-686.

Hall, H. N.: "How to Analyze Waterflood Injection Well Performance," World Oil (October, 1963) 128-130. 
Thakur, G. C.: “Waterflood Surveillance Techniques - A Reservoir Management Approach," JPT (October 1991) 1180-1188.

Terrasciences Reservoir Analysis Package (Version 5.4), Terrasciences, Inc., Littleton, CO, USA, 1994.

Perkins, T. K. and Kern, L. R.: “Widths of Hydraulic Fractures” JPT, (September, 1961) 937949, Trans., AIME, 222.

Matheron, G.: “The Theory of Regionalized Variables and its Applications,” Cahier No. 5, Centre de Morphologie Mathematique de Fountainbleau (1971).

Kelkar, M.: “Introduction to Geostatistics," Tutorial Paper presented at the 1991 International Reservoir Characterization Conference, Tulsa, OK.

Xu, Wenlong and Journal, A. G.: “GTSIM: Gaussian Truncated Simulations of Lithofacies,” Report-6, Stanford Center for Reservoir Forecasting, May, 1993.

SAS (Version) 6.08,SAS Institute, Cary, NC, USA, 1993. 